\title{
... e no começo era a fome: três movimentos da dietética na criação do homem
}

\author{
Henrique Figueiredo Carneiro
}

Curiosamente, os mitos que conhecemos para dar conta da existência humana tocam indiscutivelmente a presença da dietética, como condição inerente à hominização do vivente. Isso pode ser constatado nos mitos do Gênesis, de Theuth $e$ do Pai da horda primitiva, mediante o texto "Totem e tabu". Essa constatação torna atual o aforismo de Schiller, ressaltando que a fome e o amor aparecem como a mola do universo.

Essa questão, impõe, de princípio, uma reflexão sobre a importância do traço da dietética como uma marca na qual o homem constrói, mediante essa ação, um sentido à existência. Com isso, trabalhamos com a hipótese de que a dietética possibilita uma referência epistêmica constante para o entendimento do lugar que o homem ocupa subjetivamente em determinada época; e, sobretudo, apresenta-se como uma linha de trabalho psicanalítico promissora, quando ratifica $o$ sujeito como um produto da passagem realizada da natureza à cultura.

Palavras-chave: Dietética e psicanálise, mitos e estruturação do sujeito, dietas e subjetivação 
$1^{2}$ Movimento

"... e no começo era a fome"

$\mathrm{Na}$ dimensão paradisíaca do Jardim do Éden, não fosse a presença de um ato dietético, o homem certamente não conheceria os confins da terra, nos moldes descritos no momento da expulsão dos limites do Paraíso.

A referência explícita no começo da Criação à expressão “... E no começo era o verbo" ganha consistência de lei, exatamente a partir do momento em que o Criador indica a existência no centro do Paraíso de uma árvore da Ciência do saber do bem e do mal. Significa dizer que a hominização do casal primogênito não seria possível, se, num determinado momento, o saber não houvesse sido mediatizado por uma dieta que ficou conhecida pela ingestão do fruto proibido. $\mathrm{E}$ mais: podemos trabalhar com a possibilidade de alteridade somente quando Adão e Eva dão um sentido à vergonha experimentada pela constatação da diferença, após a ingestão do fruto proibido. Os corpos que habitavam até então - e que pareciam nada significar -, são revestidos com as folhas da árvore proibida, demonstrando um traço de humanização que ficou conhecido como a vergonha relacionada exatamente com as partes pudendas. Com isso, começa uma relação muito estreita entre o verbo e a fome. Aparece também a hipótese de que, para o verbo imperar naquele que nasce para ocupar o lugar de homem, primeiramente há de atravessar o mandato de uma sensação primitiva, de ordem bruta, aquilo que costumamos chamar de fome.

Entretanto, o verbo ganha força na dimensão do homem quando a fome encontra um paradigma de saber. Esse é o primeiro ponto da nossa articulação para mostrar que a necessidade de comer cede espaço a uma outra coisa distinta, algo que se equipara à vontade de saber. Isso indica que não podemos trabalhar com a fome, contentando-nos somente com 
o seu estatuto real. Havemos de ultrapassar essa barreira e nela buscar um passo importante na construção de um lugar subjetivo que o homem enfrenta como condição essencial para sua hominização.

Aliada à premissa de que a fome sofre uma torção desde o princípio do mito da Criação, aparece um outro apoio oriundo da noção de construção de saber e que emerge nada menos como a possibilidade de o homem contextualizar-se num movimento de sexuação. Dessa forma, fome, saber e sexualidade aparecem como três dimensões desencadeantes da possibilidade de hominização viável, inexistente em qualquer projeto anterior a esse momento.

Do ponto de vista dietético, podemos perguntar: qual foi o primeiro conhecimento que se deu depois da ingestão do fruto proibido? Essa resposta podemos encontrar no Gênesis 3,7, momento em que Adão e Eva abriram os olhos e perceberam que estavam nus. Essa parece ser a constatação da sexualidade. Uma primeira referência ao homem e à mulher; uma primeira caracterização do homem e da mulher; enfim, da ocupação do lugar do masculino e do feminino. É o momento em que os corpos, já atravessados por um sentido de masculinidade e feminilidade, começam a exibir uma espécie de sensualidade. Um franco convite à presença do desejo. É o momento em que, pela primeira vez no mito da criação do homem, declara-se a presença do erotismo.

Curiosamente, essa capacidade de perceber aquilo que antes era imperceptível, aparece na narrativa como a "Tentação de Eva". Traz como figura geradora da ação enigmática a presença da serpente, uma personagem que tenta o nosso casal primogênito, simbolizando uma condição de acesso ao saber, isto é, uma promessa de discernimento que acenaria, incontestavelmente, com uma mudança significativa na percepção das coisas, pois anteriormente não possuía nenhum sentido de diferenciação.

Encontramos, ainda, na persecução de uma referência entre a sexualidade e o Paraíso, o dado de que a sexualidade passa necessariamente pela exigência de construção de um saber. Antes existiam dois seres aos quais o Criador chamou de macho e fêmea, porém, totalmente descaracterizados de um erotismo. Nesse sentido, o erotismo, além de aparecer depois da desobediência de uma Lei, reflete também uma conseqüência que advém do jogo entre os membros da dupla primogênita. Um jogo que envolve a ação de comer o fruto da árvore proibida, que antes havia sido apresentada pelo Senhor como um limite à incomensurável possessão paradisíaca; e a figura da serpente, representando o quarto personagem que irrompe simbolicamente na trama, para proporcionar a ação carregada de erotismo, dentro desse Paraíso dessexualizado que era o Éden.

A lei, o bem, o mal, o saber, o jogo e o erotismo aparecem como os principais elementos que extraímos do livro do Gênesis para a construção do conceito de sexualidade no processo de sexuação dos corpos diferenciados de Adão e Eva. 
Da análise realizada até então, podemos deduzir que, antes da sexuação dos corpos de nossa dupla primogênita, existiam a lei e a referência ao bem e ao mal. Em contrapartida, o erotismo fundou-se somente a partir do instante em que se supera a primeira fase e, sobretudo, quando essa aparece vinculada a um saber que a serpente, metaforicamente, comparou com a promessa da sapiência divina.

Com isso, podemos articular a seguinte pergunta: que espécie de Paraíso caracterizava a existência das espécies no Éden, antes da sexuação dos nossos primogênitos?

A resposta emerge da constatação óbvia de que o Éden, ao mesmo tempo que possuía seus encantos, poderia ser definido como o lugar onde reinava uma espécie de relaxamento das tarefas árduas a que o homem foi submetido após sua queda nos confins da terra. Pelo direito de desfrutar de tudo que o rodeava - inclusive da mulher gerada a partir da sua existência - menos dos frutos da árvore do bem e do mal, o homem detecta uma faceta tremendamente enfadonha, motivo pelo qual fez com que se desenrolasse a trama, isto é, o segundo ato da história do Paraíso.

É como se nessa extrema bondade ofertada pelo Criador e que praticamente aboliu a lei do esforço para a sobrevivência do homem dentro do Paraíso, se fundasse paralelamente um Paraíso do tédio, à medida que, na sua generosa oferta, a mulher, em forma de matéria bruta, apresentada a Adão como sua companheira, era semelhante a tudo o que por lá existia; inclusive igual ao próprio Adão. Ele não a percebia desnuda. Com isso aparece o tédio ou até mesmo a apatia caracterizada como a ausência de alteridade.

Podemos então assinalar esse primeiro momento da vida do homem e da mulher como o ápice da apatia gerada pela referência da mesmidade que o Éden imprimia aos primogênitos, que haviam sido colocados no Jardim para dominar todas as espécies. Porém, como viabilizar esse domínio? Parece que nesse ponto faltavamlhes recursos para que pudessem desenvolver tais aptidões.

É dentro desse universo da mesmidade que o Criador pôs à disposição de Adão e Eva elementos para que o projeto de hominização fosse levado a cabo, sempre que rompessem com essa perfeição insuportável, fundando, conseqüentemente, o estatuto da alteridade. Os elementos que sobressaem aqui são: a lei, uma referência dicotômica (o bem e o mal) e, finalmente, o indício de um saber que o Criador sugere ao casal primogênito, equiparável ao seu.

A importância da diferenciação entre a mesmidade e a alteridade aparece como o ponto de inflexão mais importante, mais significativo, para o entendimento da eclosão da sexualidade, em forma de percepção erótica e sensual, experimentada por Adão e Eva depois de uma atitude carregada de um movimento dietético.

$\mathrm{O}$ ato dietético, plasmado na ingestão do fruto proibido, traz consigo uma série de traços característicos dos vícios humanos: a vergonha, a inveja, a gula, aquilo que entre tantas denominações se aproxima dos sete pecados capitais. 
Para que isso aconteça, é necessário ressaltar um primeiro elemento definidor dessa articulação paradisíaca, a presença inexorável da transgressão constatada no espaço da hominização do casal primogênito. Ela aparece como o ponto de conexão. Sem ela nada existiria. Admitir esse ponto de partida implica também aceitar o projeto de homem concebido no Éden dentro de uma dimensão falida, na medida em que a conciliação entre ele e a demais espécies fazia-se impossível. Ainda que tenha sido criado para dominar, a proximidade harmônica reinante no Paraíso vai promover essencialmente uma tremenda confusão entre os seres, passando a ser uma tarefa mister a invenção de um processo de diferenciação entre as espécies e, sobretudo, do homem com o próprio semelhante.

Nesse sentido, a Lei funciona como uma espécie de reparação diante da idéia de que, apesar de a mulher ter sido criada a partir do homem, nem todos os dias o Criador estava disponível a operar o sopro divino nas narinas de um descendente, tampouco lhe correspondia extrair, continuamente, a criatura mulher a partir das costelas do homem.

O reparo que se instaura desencadeia o surgimento de uma sexuação, abrindo uma via à reprodução humana, e transforma um trabalho artesanal do Criador numa possibilidade viável da multiplicação do homem. Com essa torção resultante num processo de reprodução sexuada, fica mais fácil a viabilização do mandato divino "Crescei e multiplicai-vos". Tudo isso só foi possível com a criação de uma lei aberta à transgressão; uma transgressão que, por sua vez, aparece mediatizada pela via dietética simbolizada numa árvore dicotômica, cuja construção de sentido abria uma rachadura sobre a harmonia paradisíaca e lançava o homem, agora hominizado, nos confins de uma divisão, que o ejetava também sobre um lugar, um mal-lugar, enfim um mal-estado.

As conseqüências desse mal-estado, propiciado por um movimento dietético, implica também dizer que o processo de sexuação em si passa a ser a grande tarefa de representação do homem quando busca uma adjetivação para esse mal-encontro com o Outro sexo. Desencontrar-se da tediosa condição harmônica paradisíaca implica o encontro com a sexuação, no prazer, no desprazer, no sofrimento, no trabalho, na dúvida. Todas essas condições, agora inerentes ao homem, reclamam dele uma resposta para que possa suportar tantas limitações e seguir com sua nova condição.

Essa nova condição que o homem havia de enfrentar, e que repercute na sua condição hominizada, reclama à sexualidade uma forma também de suporte. Ou seja, como levar avante essa nova condição de mal-estar se algo não fora criado como suporte? É nesse ínterim que podemos sacar toda a construção da resposta ao que emerge como constatação da diferença advinda da sexuação como lugar de morada. Responder a essa morada é algo suportável em termos das criações fantasmáticas 
levadas a cabo pelo homem. Aqui entendemos criação fantasmática como a forma mais lúdica possível que o homem encontrou para responder o insuportável habitat da sexuação.

Essa resposta lúdica diante da condição de morada no mal-estado da hominização vai aparecer exatamente como uma saída artística, recriadora, enfim, uma via que o homem encontra pela esfera do jogo. Jogar com o mal, com um estado, com uma condição, sempre em busca de um suporte. Se o jogo da nossa parelha primogênita se apresenta como aquilo que aparece no tabuleiro da alteridade, a implicação dele só pode ser entendida no espaço do múltiplo. Jogar com o outro é o que dispõe, pois não há mais a harmonia possível da mesmidade, condição aniquiladora de articulação fantasmática.

Como condição humana, o jogo vai aparecer no espaço da matriz primogênita exatamente no lado do dicotômico. É no espaço causado pela transgressão e que instaura um mal-estar onde podemos imaginar o jogo. $\mathrm{E}$, se a nova condição que hominiza o antes harmônico denota sobretudo uma sexuação, o jogo haveria de ser montado exatamente no espaço correspondente.

Jogar com esse lugar implica, portanto, lançar mão de Eros. Erotizar esse estado de mal-estar aparece então como a primeira condição de suporte simbólico da sexuação como lugar de morada. Dessa forma, o erotismo já aparece como uma condição banida do estado anterior à hominização. Significa dizer que, no Paraíso, não havia lugar para Eros. O erotismo não se instaura ali onde governa o reino da harmonia, senão que aparece como uma criação, como uma forma de resposta construída pelo homem na sua condição de artífice de saídas sobre o mal-estar.

Nessa mesma linha, é valida a hipótese de que não há possibilidade de existência de sexualidade no Paraíso. Esse, por cultivar o discurso da mesmidade, reserva para os que não habitam suas dependências a possibilidade dos encantos sensuais e eróticos, pois ali não existe alteridade. As consequiências que podem advir dessa construção demonstram ser deveras interessantes. Nessa mesmidade reinante, não se admite a possibilidade de prazer, uma vez que a impressão gravada na vida monótona que ali reinava apaga qualquer possibilidade de desprazer, isto é, como assinalar a existência do prazer no Paraíso, se não havia desprazer como seu contraponto? Esse só pode ser um princípio reconhecível para os que abandonaram suas dependências. Somente quando aparece um homem situado num lugar de malestar advindo de um processo de sexuação, podemos admitir a possibilidade de obtenção de prazer. Conseqüentemente, algo passa a existir além desse princípio do prazer e que sustente uma meta referente à saída do mal-estar.

Já se percebe até aqui que o preço pago pelo homem, inerente à sua condição estruturada de hominização, implica ao mesmo tempo uma busca pelo perdido, forçando-o a construir um saber sobre a felicidade e, por suplemento, uma clara insuportabilidade de convivência com a descaracterização do humano que o Paraíso 
apresentava. Definitivamente, não há lugar para o homem dentro dos muros do Paraíso, uma vez que ele está destinado aos seres que não possuem a capacidade de eleição. A partir do momento em que o homem foi atravessado por essa capacidade, prefere pagar qualquer preço para sair do estado monótono que se anuncia no Paraíso.

Nesse primeiro movimento dietético situado no mito da Criação aparece seu contraponto. O mesmo homem, que paga tão caro por esse traslado à terra e que se submeteu à lógica dos contrários, é o mesmo que adjetiva de paradisíaco seus influxos de gozo, em direção ao sonho de encontrar a felicidade. Se a terra é o espaço que possibilita as experiências contraditórias, descompletas, parcialializadas, que permite incluir a possibilidade prazer e desprazer, de vida e de morte, então, toda associação possível de elementos que se possam acoplar, com o construto dietético desencadeado pela referência à construção do saber sobre a árvore da ciência do bem e do mal, passa a exibir traços de um desejo de reencontrar um prazer que adquira qualidades de totalidade, tal e qual pudemos acompanhar na hipótese de uma harmonia plena paradisíaca. A felicidade assemelha-se então a essa hipótese do Paraíso perdido. Assim, sendo uma experiência hipotética, a de que o homem abandonou o Paraíso por não suportar a idéia de um gasto igual a zero, em contrapartida, tende a recordálo como uma espécie de utopia factível, sempre e quando se veja submetido à intempestiva condição de habitante do mal-estar.

Esse parece ser um dos pontos importantes da nossa reflexão. O homem dietetizado com o fruto do saber do bem e do mal passa a exibir traços da existência por meio de impulsos que se dirigem às coisas que o Criador lhe mostrou. A monotonia é na verdade o que o homem não sustenta na sua existência, considerandose a premissa hominizadora de que apareceu um saber a ser construído sobre sua nova condição humana. Visto por esse prisma, o saber desencadeado pela experiência dietética do fruto proibido apresenta-se como o causador do fracasso do projeto paradisíaco, ao mesmo tempo em que experimentar sua possibilidade e permanecer no Paraíso é a grande meta utópica que cada sujeito tende a alcançar, sob os auspícios da felicidade.

A felicidade como suposição de reencontro do prazer total é a própria insistência sobre a vertente monótona do Paraíso. Ela descaracteriza a experiência dietética propiciada pela árvore do bem e do mal. É uma tentativa de extradição a posteriori daquilo que, mesmo nunca existindo, articula a hominização do projeto de homem. $\mathrm{O}$ homem do prazer total sempre esteve morto à nossa realidade, fato que implica uma dedução lógica: o prazer total é algo reservado à dimensão da morte. Dessa feita, deduzimos que, para o homem afirmar-se enquanto tal, foi necessário arquitetar uma fuga da monotonia auferida pelo Éden. Uma saída do reino dos mortos, lugar do harmônico, para habitar a terra, lugar da sensualidade e do erotismo, enfim, lugar da alteridade. Ao mesmo tempo, ficam caracterizados os lugares do prazer e do desprazer, na medida em que, quando se alcance o nível máximo do primeiro, esse 
nunca chegará a esvaziar o homem de suas tensões ao ponto de alcançar o nível zero, ao menos que chegue à morte como plenitude da monotonia. Em definitivo, o Paraíso está reservado aos mortos. Conseqüentemente, a terra está destinada, desde sua invenção, aos vivos, e, a estes, se reservam nada menos do que pequenos influxos paradisíacos, incompletos, tendo em vista que, ao desfrutar do prazer, acercam-se o máximo possível do Paraíso, isso se levamos em consideração o fato de que as tensões que suportam diminuem a um nível máximo possível à condição de vivente. Diminuir a tensão deflagrada pela ocupação do lugar de mal-estar a um nível mais próximo a zero não é o mesmo que igualá-la a zero. O sujeito, ao não morrer no desfrute de uma experiência de prazer, conseguirá no máximo aliviar sua tensões a um nível tão baixo que se inclinaria a dizer que desfrutou de algo semelhante ao que, supostamente, vivenciaria no Paraíso. Nesse sentido, a expressão está empregada de forma bastante coerente, quando se ouve de alguém que determinada experiência foi paradisíaca.

Finalmente, o que fica revelado com toda essa dinâmica vivida a partir da ingestão do fruto proibido é que se funda a partir daí a presença da dietética em todos os movimentos contidos nos espaços da dicotomização do homem. Isto, dedutivamente, seria pensar o homem por intermédio das dietas não mais concretas, ou em estado bruto, senão com base nos espaços de limites trazidos com a parcialização que constrói um sentido à sua existência. Esse espaço funda com a hominização da parelha primogênita no mito da Criação, nada menos que a dimensão ética que a dietética suporta.

Esse movimento dietético vislumbra, ainda que sub-repticiamente, a verdadeira aptidão ética do sujeito, tendo em vista que nele se contempla a emergência de uma sexuação em decorrência de uma lei. Dessa forma, a sexuação relaciona-se com a cadeia que se constrói do lado suplementar à monotonia que antes reinava nos limites do Paraíso. A maior das lições éticas que pode ser extraída da experiência do Gênesis a partir da óptica da sexuação e do Paraíso é que, entre o prazer paradisíaco monótono e a realidade terrena sensual e erótica, existe uma ruptura da qual nenhum saber pode dar conta. Esse será sempre um lugar inerente ao mal-estar.

$2^{2}$ Movimento

$$
\text { “... e no começo era o verbo" }
$$

O segundo movimento que a dietética impõe à existência do homem submetido ao lugar do mal-estar, típico de quem perdeu o convívio com a suportabilidade de uma harmonia predominante, aponta em direção ao que ele pode tentar recuperar para situar como possível índice redutor de suas inquietudes. 
Se com a sexuação deflagrada se fez presente a demanda de construção de saber, esse segundo movimento é aquele que vem atender nada menos do que o ideal de justa medida em relação aos objetos que podem ser evocados para eliminar a transparência do mal experimentado no espaço do lugar ocupado.

Nesse sentido, qualquer objeto pode servir muito bem, tanto ao propósito de cura como o seu contrário, à intenção de veneno. Não há mais plenitudes possíveis, desde que o homem foi ejetado nos confins da terra. Como ocupante de um malestado, o homem agora há de tentar formas opcionais de regresso à concepção paradisíaca perdida. Dessa forma, um grande passo para responder a esse mal-estar pode ser refletido por meio da invenção do Phármakon, algo da ordem impossível de ser definido como o que preenche o lugar do bálsamo ou do veneno.

Nosso Criador agora é aquele que, investido de fazer valer a premissa de que “... e no começo era o verbo", vai defrontar-se com a invenção da escritura. O Pai do verbo rechaça a criação do filho, dizendo que, tendo em vista que a escritura foi inventada objetivando a memória e a instrução, seus efeitos serão contrários, exatamente porque, ao confiar nos escritos, a ênfase recairia sobre o aspecto externo da memória, isto é, a uma rememoração, totalmente distinta dos objetivos internos da memória do Pai.

Dessa forma o Phármakon aparece como uma referência à dietética, sob a forma de escritura, que por sua vez evoca uma conotação moral. Diz-nos Derrida que é exatamente a moral que está em jogo, “... tanto no sentido da oposição do bem e do mal, do bom e do mau, quanto no sentido dos costumes, da moralidade pública e das conveniências sociais. Trata-se de saber o que se faz e o que não se faz. Essa inquietude moral não se distingue de modo algum da questão da verdade, da memória e da dialética". (1972; p. 17)

Aqui o foco principal aparece na pergunta sobre qual a conveniência da escritura. $\mathrm{E}$ isso abre uma nova perspectiva na nossa construção sobre a grandeza da criação do homem e o seu habitat natural do mal-estar. O homem, atirado aos confins da terra e submetido ao mal-estar, agora há de criar uma forma de registro dessas memórias, talvez com o fim de passar suas impressões ao outro.

Theuth é considerado na mitologia egípcia como o pai do jogo e da escritura. $\mathrm{Na}$ sua invenção, os caracteres da escritura tinham por finalidade a apreensão de um aspecto deveras importante para o sentido da existência humana, ou melhor, para uma articulação da cultura hominizada: perpetuação do memorável.

Esse segundo movimento da dietética é claramente dirigido aos que se situam entre os espaços do bem e do mal, preocupados essencialmente em alcançar a memória que faculte o acesso à felicidade.

Como habitante do lado humano, quem persegue tal objeto pelo lado da escritura vai encontrá-lo como um remédio/veneno diante do esquecimento. Foi esse um artifício de Theuth, preocupado com a desmemorização do homem. O Pai, 
Thamous ou Amon, por não necessitar de registros, certamente condena a invenção da escritura. Entretanto, como no mito da criação do Éden, no qual aparece um artifício relacionado ao saber do Criador, aqui se apresenta uma técnica para aqueles que, não sendo o Pai, pretendiam o acesso à memória. É nesse sentido que no Phármakon está presente uma certa dose de subversão ao lugar do Pai como donatário do saber pela fala. No Phármakon está presente um forte desejo de matar aquele que se basta com o verbo. Há um desejo parricida transcrito na presença da escritura e que fez Derrida perguntar-se se o Phármakon não seria em si "um criminoso ou um presente envenenado", presente exatamente no momento que é ofertado ao Pai.

Esse segundo movimento dietético já anuncia, sabiamente, que qualquer tentativa de matar o Pai é vivificante, tanto para o filho quanto para o ocupante do lugar do Pai, como referência estruturante do Filho. Aqui, o Pai é indício de um bem, uma certa metáfora econômica de um capital perante o qual o filho contrai uma dívida. E é essa dívida que entra na economia do movimento dietético que a escritura, como Phármakon, apresenta como remédio ou veneno no processo de rememorar aquilo que somente o pai detém, na sua qualidade de apreensão da fala.

Esse é o autêntico movimento dietético que justifica “... e no começo era o verbo", demonstrando sua importância exatamente porque, por meio da escritura proposta ao Pai, Theuth aspira nada menos que à propriedade de um saber inerente ao detentor da memória; isto é, pretende a eliminação do esquecimento por meio da perpetuação do dito registrado na escritura. De fato, nos diz Derrida, depois de trabalhar com as variantes dos filhos de Thamous, que eles são tantos quanto necessário for o jogo da escritura. Eles podem ser Theuth, Thoth, entre outros. Fundem-se em si, suscitando nada menos que a escritura e a medicina, abrindo um espaço para a existência do Phármakon, como possível remédio ou veneno: "O deus da escritura é pois um deus da medicina. Da 'medicina': ao mesmo tempo ciência e droga oculta. Do remédio e do veneno. O deus da escritura é o deus do Phármakon. E é a escritura como Phármakon que ele apresenta ao rei no Fedro, com uma humildade inquietante como desafio". (ibid.; 38)

Com isso, podemos retomar o $1^{\varrho}$ movimento da dietética no Livro do Gênesis e mostrar que ele, desde a premissa da eliminação do harmônico insuportável e a fundação das brechas dicotômicas, reflete-se no $2^{\theta}$ movimento, o do processo de criação da escritura, por meio das opções para as construções de sentido que o homem encontra diante das penúrias da condição humana. Significa dizer que, a partir daí, o homem há de trabalhar arduamente, uma vez que foi ejetado nos confins de uma outra terra que, extrapolando os limites do físico, traz à tona outros limites, ou seja, o da própria existência.

Emergem, então, inúmeras possibilidades combinatórias. Esse é o novo preço que a dietética, em sua outra versão, impõe mediante a escritura; adietar-se de signos, 
de hieróglifos, empanturrar-se de letras, e delas extrair o sentido da memória daquilo que se disse. Depois de haver comido as letras, uma constatação: não há sentido viável para a memorização do dito. O dito foi dito, só resta um espaço factível de ser ocupado, da ordem da rememoração. $E$ isso porque cada um pode adietar-se com os registros propiciados pelos hieróglifos criados na tentativa de apreensão da fala, porém, da combinação significante emergem infinitas possibilidades de significação da miséria humana.

Essa escritura, tal e qual as qualidades de Thoth, é índice de cura e de envenenamento. Ambos se apresentam como uma possibilidade na construção do saber, na medida em que poderão, pelo registro escrito, acumular saber, sapiência, reeditando a figura da serpente e a tentação de elevar-se ao saber do Pai. Esse parece ser aqui o grande desfecho da dietética. Nesse segundo movimento, deixa transparecer que confiar no discurso significaria cair exatamente na insuportabilidade do saber insinuado pelo Pai. Como consolo, a escritura emerge para os mortais hominizados como índice somatório. E Thoth, além de ser o inventor da escritura e do jogo, também criou o número.

Entretanto, se o mal-estar desencadeado pela impossibilidade de o homem fazerse deus vai suscitar precisamente a percepção de que o significante impõe uma cadeia combinatória eterna, pois é Amon quem, tal e qual o Criador do Éden, vai apontar seu descontentamento com a invenção do filho. Diz que a técnica da escritura vai relaxar o poder da fala, e, condenando a ousadia do invento que pretendia aproximarse da sua onisciência, aponta na descoberta a presença de algo da ordem de um "tereis que penar pelo saber de sua existência". Um penar que não mais se limitaria à sobrevivência pela manutenção do corpo, e sim pela luta constante que os significantes impõem ao homem quando esse utiliza os hieróglifos da escritura. A grande pena é que, além da incessante combinação significante, essa traz consigo o mundo da incerteza quanto ao saber construído. Há uma variação de sentido tão efêmera quanto os fins e objetivos traçados.

Assim, a escritura é criada pelo homem num autêntico movimento dietético, no qual o filho, além de tentar o acesso ao verbo paterno, encontra-se com o mimetismo do significante que cura e mata, por meio do sentido construído. Isso dependerá de como será empregada pelos aspirantes às qualidades paternas do saber. Ela é medicina, e, como tal, pode ser excesso, falta, gasto desmedido, enfim, ela pode matar e fazer renascer.

Dessa forma, o $2^{2}$ movimento da dietética na criação do homem destaca outra grande dimensão ética dentro do aspecto da hominização. O sentido da combinação hieroglífica sugere algo que está situado sempre além do registro. Pressupõe que, ao ler aquilo que foi dito, o sentido extraído da leitura põe o homem no lugar que ele mesmo significa. Em decorrência disso, qualquer decisão processada pelo homem o deixará plantado no espaço do mal-estar. Não mais se come do fruto proibido 
oferecido pela metáfora da maçã do Paraíso. Agora, o centro do Paraíso, algo que joga com o lugar da árvore do saber do bem e do mal, não é mais algo tão factível, apesar de conduzir à constatação de um fato que leva o homem inclusive à morte. Dessa feita, o que se encontra no centro de referência ao homem e que o fará quebrar com a monotonia da escuta do "... e no começo era o verbo" será a própria essência do saber que o Pai um dia insinuou. Se no Éden o insuportável é da ordem do harmônico, no mundo alardeado pela fala, o insuportável será o esquecimento pela falha da memória. A escritura aparecerá como a possibilidade de rememorar aquilo que se disse.

Com isso, um outro aspecto demasiado humano começa a aparecer dentro desse movimento dietético. $\mathrm{O}$ verbo em si, na sua condição de locução, é deveras tedioso. Há algo a ser feito sobre a esfera daquilo que se ouve, como condição de acesso ao proibido. Ao provar da combinação hieroglífica, fica mais evidente algo de uma outra ordem. É o surgimento do engano e das demasiadas certezas, ou seja, tudo aquilo que a interpretação poderá conclamar quando o Pai da fala não estiver mais presente para defender o dito.

É dessa forma que se experimenta a presença da dimensão ética descoberta no mito da criação do homem pela escritura. A questão ética instala-se no interdito, rompendo com a harmonia do dito pelo Pai da fala. É essa a grande aportação à instauração do mal-estar criado a partir do homem do registro. É por meio dele que se abre um espaço que rompe com o insuportável interlocutor que tudo diz ou que, ao menor sinal de interpretação, responde, antecipando-se a qualquer possibilidade de engano.

É nessa composição que Thoth aparece como o filho-deus, aquele que congrega e desagrega letras e "farmacéia". É assim que o Phármakon, escritura, droga e remédio, não é nem um nem outro; e, como contraponto, pode ocupar de forma cambiante os dois extremos da odisséia humana.

No aspecto da promessa de felicidade, tudo aquilo que venha ocupar o lugar de recuperação do discurso do Pai aparecerá como indícios do retorno viável. Se no Éden a promessa do menor esforço descobria um movimento dietético insuportável para o hominizado e, a posteriori, permanecia como índice de um Paraíso perdido, no mundo do verbo qualquer interpretação permitida pela combinação de significantes e que, sobretudo, envolva o homem na articulação de um saber, poderá vir a ser o sinônimo de felicidade. É algo que se assemelha à verdade.

O curioso é que, a partir desse segundo movimento, as coisas, os objetos passam a ganhar força de verdade, quando atravessadas pelo sentido da interpretação. É nesse sentido que as drogas atravessadas pela escritura, e prescritas mediante um saber constituído, podem alcançar o poder de cura ou de envenenamento.

A medicina é essencialmente uma arte dietética. Visto por esse prisma, o artífice, lugar ocupado por quem pratica as artes médicas, prescreve regimes e adieta o homem 
com vistas a que este alcance um certo ideal perdido. A saúde aparece como uma grande meta que move o homem em direção ao Paraíso perdido, porém, o que a faz aparecer nas preocupações da medicina é exatamente seu contraponto conhecido como a enfermidade. O Phármakon prescrito pode muito bem alcançar, dentro da variância dos objetivos do homem, o sentido da cura ou do envenenamento.

Da dieta da escritura, sob a forma de prescrição, à dieta da ingestão, o passo estabelecido é deveras estreito. O sentido da ingestão pode ser mortífero. Aniquila, restabelece, estimula, entristece. A droga como promessa de felicidade, traduzida na trivialidade da concretude rotineira, extrapola também o próprio ato da ingestão e conclama o harmônico do real do corpo, mediante o reencontro com a fala do Pai. Um Pai que sempre exercita sua memória, sem precisar rememorar como o filho, prestando-se, por isso, como índice de algo perdido.

É nesse sentido que a dietética é tida, no movimento de fundação da medicina, como aquela que, extrapolando os valores diretos da prescrição da droga, alcança os limites da arte de viver. Com isso, deflagra todo um movimento ético que indica, sobretudo, uma referência ao regime como "... uma categoria fundamental através da qual pode-se pensar a conduta humana; ela caracteriza a maneira pela qual se conduz a própria existência e permite fixar um conjunto de regras para a conduta. (...) O regime é toda uma arte de viver". (Foucault, 1984; pp. 92-93)

Como algo inerente à arte de viver, que filtra os costumes e a própria conduta humana, o que apareceu dentro desse segundo movimento abre espaço para o que, já em voga nesse instante, exige uma análise num outro mito que, partindo do percurso realizado entre a fome e o verbo, dê conta, sobretudo, daquilo que já foi descortinado nos limites do Paraíso mediante a criação do erotismo como jogo.

\section{$3^{0}$ Movimento}

$$
\text { "... e no começo era o amor" }
$$

Nosso pai aqui já não é o da Criação do Universo, aquele que haveria de inventar o homem a partir da matéria bruta. Esse pai, como vimos, encontrou mediante a instituição da proibição um movimento dietético que concluiu com o homem expulso da categoria da mesmidade. Tampouco é o pai da fala, aquele que haveria de condenar a criação da escritura, exatamente por assemelhar-se a um Phármakon, símbolo máximo da dieta plasmado nos costumes do excesso e do gasto. $\mathrm{O}$ pai que agora se vislumbra é aquele que aplica sobre a hominização nada menos do que algo situado além da fome e do verbo, algo que está exatamente plantado na dimensão do amor. Algo da ordem da lei.

Esse é o pai que, por si mesmo, faz a diferença frente aos filhos. E já o faz perfeitamente situado nos confins da terra. Esse já é o pai hominizado, carregado 
em si mesmo de excesso, possuidor de um vício que se desenha pelo lado do amor. E será exatamente a respeito do amor que aparece sob a forma de erotismo que o terceiro movimento dietético fincará suas bases na criação do homem.

Os pais que o antecedem são distintos em dois aspectos: um que se caracteriza além da fome, do verbo e do amor, ou seja, é o verdadeiro Pai da Unicidade, ponto de derivação das coisas e da vida, a partir do nada; o outro, pela condenação da escritura, em detrimento da fala, introduz a tarefa árdua da significação. Esse pai da horda se inclui no índice de sexuação exatamente pelo que exibe de desejo erotizado nas relações de posse com as mulheres. Já é o pai que possui todas as mulheres e que, ao mesmo tempo, potencializa exceção. Ele possui e é único. Como único é indício de desejo. Tal como o pai da fala, suscita um parricídio. Ao fazê-lo, cria a unicidade do homem, exatamente pela via do desejo. É o pai mais recente, é quem evoca ares de civilização. Como mito fundante do homem, e criado no meio da modernidade, esse pai cria laços mediante o remorso e a culpa, índices bem diferentes daqueles sentidos por Adão e Eva, traduzido como vergonha ao perceber que estavam nus e sensualizados. Também é distinto de Thoth, que em dado momento confunde-se na figura do pai, mediante a capacidade de matar ou salvar pela referência ao Phármakon.

Esse é o pai que funda um movimento dietético antropofágico. É um convite à degustação real da carne. Como tal, é um pai que evoca a concupiscência. E é nesse movimento, apesar de parecer o mais brutal de todos até então anunciados, em que se apresenta um dos mais sutis impulsos que engloba os dois anteriores e dá conta da dietética na atualidade.

Sobre essa sutileza nos fala Lacan, no Seminário VII, quando comenta a "Morte de Deus”. Diz ele: “... para que algo da ordem da lei seja transportado, é necessário que passe pelo caminho do drama primordial, articulado no 'Totem e tabu'" (195960; p. 213). Essa sutileza indica que, no movimento dietético da ação antropofágica, o que se revela é a presença da lei, ou seja, algo da ordem estruturante da existência humana. $\mathrm{O}$ homem se estrutura pela boca, poderíamos dizer; tendo em vista que, ao mastigar os pedaços do pai, o sabor que resta da ruminação que obriga o filho a dar um sentido a ação desenvolvida demonstra sutilmente em que lugar ele está a partir dali, em relação ao pai. É de uma refeição totêmica, que nada teria de questionarmos se foi real ou não, na qual a carne paterna foi usurpada e retirada da relação real com todas as mulheres, que o filho vai potencializar um sentido para a própria carne. É aqui onde ele há de situar pouco a pouco em que lugar sua própria carne deve vibrar, arder e, finalmente, padecer no gozo que o corpo experimenta.

É nesse movimento dietético, em virtude das implicações que o sentimento de culpa imprime ao homem, no qual o postre deixa transparecer que, ao invés do primeiro prato haver servido aos objetivos do acesso aos deleites da potência do pai, 
ele restringe, limita e deixa nas entrelinhas da digestão uma interdição. O homem há de interdizer o que comeu.

$\mathrm{O} 3^{2}$ movimento é sábio porque indica que a lei se articula com algo da ordem do amor. A interdição produz fantasmas, tendo em vista que o filho há de produzir saídas para o gozo limitado com a devoração do pai. As saídas que o filho encontra para potencializar sua existência são todas retiradas desse movimento. E, na articulação fantasmática construída a posteriori, reaparece algo do jogo erótico, típico do $1^{\varrho}$ movimento, em que o homem, condenado a trabalhar para justificar sua sobrevivência, mescla jogo e trabalho, inclusive para suportar o trabalho do ato. Não poderia haver ato sem a articulação fantasmática. Ao mesmo tempo, não haveria articulação possível se o amor não fomentasse essa promessa de felicidade.

É aqui onde o $3^{0}$ movimento dietético é rico em referência aos demais mitos. Se é no amor que a promessa de felicidade mais se anuncia na existência do homem, o terreno do mal-estar vai trazer à tona o essencial do construto freudiano estruturante do mito do pai poderoso, como pedra fundamental da articulação com o mal-estar na civilização. O amor move o mundo em busca da felicidade. Por intermédio dele se mata, se aniquila. Porém, o que ele deflagra, em contrapartida, é o terreno em que o sujeito se encontra. Em definitivo, ele revela que a cada encontro a interdição, como essência do mal-estar, se faz mais presente. E nem por isso ele deixa de tentar. Por que?

Essencialmente porque existe um mandato, um imperativo de gozo que também nasce desse movimento dietético e que après-coup pode ser lançado como análise sobre os outros dois movimentos. Desse $3^{2}$ movimento, fica claro que o homem interditado do gozo pleno lança-se em sua procura, encontrando a cada tentativa o limite imposto pela instauração daquilo que a degustação do pai inscreveu. Numa articulação mais profunda, significa dizer que a dieta que o pai impôs aos filhos, por meio de seus próprios movimentos, indica que, junto à lei, existe a presença inexorável de um mandato em direção à transgressão. E para que transgredir? A resposta seria mais óbvia: para sentir o sabor imposto pela interdição. É por isso que se diz desse imperativo que ele ordena que o sujeito goze. Dito com outras palavras: todo imperativo de busca de felicidade passaria, obrigatoriamente, por essa possibilidade do filho reencontrar-se em um dado momento com a condição exibida pelo pai pleno.

É dessa forma que podemos retornar o mito do Gênesis, não mais para situar o desencadeamento da ação dietética, já assinalada por nós, senão para mostrar o desejo que se instala no homem de reencontrá-lo outra vez. Em cada ato do homem interditado, uma reedição dietética se faz presente. Para entendermos isso, se faz necessário aplicar o passo da metamorfose entre a comida totêmica e aquilo que se instaura no homem. Depois veremos a aplicabilidade de tudo isso no cotidiano. 
O que se constata com a fundação da lei, instituída pelo mito da horda primitiva, é que o interdito de gozo que emerge é, em si, índice estruturante para o homem nas suas demais investidas desenvolvidas pela vida. Isso implica admitir que a lógica que aqui se aplica encontra em Freud toda uma estética, diferente, por exemplo, da estética da existência promulgada pelos gregos.

A estética da existência que aparece no campo freudiano remete nada menos que à economia que aqui podemos retomar do $2^{2}$ movimento, na medida em que põe em jogo toda a dimensão da significação que a relação significante-significado traz ao homem. Lacan, no Seminário VII, lembra que a estética freudiana "deve ser colocada no ponto de partida do problema, para tratar de articular suas conseqüências, em particular o papel da idealização". (1959-60; p. 195)

Trabalhar com a dimensão de economia, partindo do significante, seria o mesmo que aplicar sobre a invenção da escritura uma outra ordem que já não mais se contenta com o argumento de que há hominização pela diferenciação da escritura em relação à fala do pai. Seria basicamente trabalhar com o pressuposto de que a escritura que trabalhamos aqui foge à necessidade inclusive de invenção do hieróglifo, uma vez que a maior das invenções relacionada ao ato da escritura fica fundada com o advento da interdição. Se há uma interdição, uma proibição, é porque ao mesmo tempo passa a funcionar algo que, partindo de uma escritura, se inscreve naquele que aspirava a igualar-se não mais à memória da sapiência paterna, senão ao nível da potência exibida pela brutal capacidade que ele tinha de aceder a todas as mulheres. Esse pai gozador, potente, supostamente o pai das ereções, é aquele que inscreve mediante a instância de uma letra que, por sua vez, também ultrapassa as marcas hieroglíficas.

A escritura é importante, porém não mais como uma condição de fazer-se humano. A prova é tal que, quem tenta fazê-lo por ela, sem as marcas da instância da letra, que por si já traz toda uma referência distinta ao ponto fundamental do $2^{\circ}$ movimento, ou seja, o esquecimento, falha no emaranhado sugerido pelo significado em que o hieróglifo aporta.

Nesse ponto, se retomamos a estética como uma idealização que aparece em toda criação hominizada, podemos chegar à lógica de que toda tentativa estética que o homem articula está fadada, pelo próprio caráter que a define, como um lugar de falência. Como lugar de falência, situamos outra vez nossa problemática no seio da discussão do mal-estar.

Há um movimento do homem em direção à concreção da felicidade que, com base em uma idealização que podemos situar no lado da formação do eu, aparece como sendo algo da promessa de uma unificação. $\mathrm{O}$ eu, tipicamente formado numa dimensão estética, leva consigo toda uma carga especular, em que o que se deixa transparecer mostra, sobretudo, que a matriz é ortopédica e que os ideais são propulsores ao encontro estético dessa mesma unificação. Entretanto, a matriz em si é que descompleta. Tocamos outra vez a condição do desejo de sermos felizes. E, 
de fato, Lacan também nos diz, e é perfeitamente comprovável, que a estética freudiana é tão-somente "uma das fases da função da ética" (ibid.; p. 195), complementando que é muito assombroso o dado de que não se discuta isso no meio psicanalítico. Finaliza essa construção, dizendo ainda que, no seio dessa discussão sobre a estética freudiana, o que vai aparecer é a indicação da existência de algo inacessível e que Freud destaca como das Ding.

Essa "Coisa" aparece exatamente na falência de todo ideal projetado como uma promessa de felicidade na vida de quem se vê hominizado. E aparece plantado como falência, ali onde qualquer projeto estético de hominização tenta, mediante o maior estatuto ético que lhe é possível, alcançar o objeto definitivamente incorporado aos seus ideais de felicidade. Nesse sentido, um dos aspectos de das Ding, da Coisa, como uma marca da hominização do homem e que, ao mesmo tempo, o lança num movimento dietético flagrante, aponta exatamente no sentido da noção de estrangeiro. Como estrangeira constante aos planos de felicidade alcançável pelo homem, o que vai transparecer é que radicalmente essa Coisa buscada nos projetos de felicidade se torna impossível, exatamente porque se assemelha à apreensão definitiva do Outro absoluto do sujeito. Ele é o próprio objeto nostálgico do sujeito, aquilo que o fará inclusive lembrar do Paraíso como algo perdido, cheio de felicidades, ainda que isso seja uma aspiração que o sujeito nunca alcança, pois, no passado, suas experiências estavam atravessadas por uma caracterização do mal-estar.

Nesse ponto, apareceria uma grande referência dietética ao homem já interditado como resposta à deglutição do nosso Pai da horda primitiva.

Nesse movimento dietético de tentativa de apreensão da felicidade, que tão-só denota a presença de um mal-estado, o que surge é a constatação de algo da ordem da origem da vida como que remetendo a uma constante alucinação. A alucinação aparece, então, como algo que, presente em toda referência humana, ainda serve para demarcar momentos cruciais de cortes epistêmicos que o homem construiu durante o seu percurso histórico nos confins da terra. À guisa de referência, se tomamos Quixote, um dos marcos indiscutíveis de ruptura com as similitudes do século XVI e com a instauração de uma outra forma de pensar, onde já não mais se admite essa espécie de leitura do mundo, o que vamos encontrar no centro da problemática cervantina será nada menos do que a presença de um ato alucinatório como índice de mudança de uma era.

Com respeito à dietética, podemos nos utilizar de uma referência à estética freudiana que Lacan nos ajuda a construir, quando diz que: “... o mundo da percepção nos é dado por Freud como dependente dessa alucinação fundamental sem a qual não haveria nenhuma atenção possível". Se paramos para refletir um pouco sobre esse construto, veremos que, em Freud, a base que o inspira a trabalhar os princípios da realidade e do prazer coloca-se exatamente a partir da experiência dietética da alucinação sobre o objeto peito. 
Portanto, a presença da alucinação no construto da existência do homem é determinante e, sobretudo, de bases dietéticas, envolvendo a estética e a ética do sujeito.

Dessa maneira, o grande referencial ético que o $3^{\circ}$ movimento demonstra é que ele representa, por meio da dietética, toda uma forma subjetiva de que o homem da modernidade se utiliza para insistir na sua existência. Significa dizer que a própria noção de inconsciente está seriamente afetada por um movimento dietético. Ou melhor, ele é um construto dietético, uma vez que, se ele está estruturado como uma linguagem e, ela, por sua vez, se situa dentro da dimensão da dinâmica dos significantes, não há como refutar essa tese.

Essa é, pois, a presença inexorável da dietética, estudada a partir de três mitos importantes, por congregar em si três movimentos, envolvendo a fome, o verbo e o amor, três condições que imprimem ao homem um lugar de mal-estar e, conseqüentemente, exigem a articulação de saídas subjetivas, respeito ao lugar que ocupa.

\section{Referências bibliográficas}

DERridA, Jacques (1972). A farmácia de Platão. São Paulo: Iluminuras, 1991.

Foucault, Michel (1984). L'usage des plaisirs. Histoire de la sexualité. (Vol 2). (Trad. cast: El uso de los placeres. Historia de la sexualidad. (Vol 2). Madrid: Siglo XXI, 1986).

Freud, Sigmund (1913). Totem und tabu. (Trad. cast: Totem y tabu. In Obras Completas. Madrid: Biblioteca Nueva, 1981, vol. 2).

Genesis. Antiguo Testamiento. In Biblia de Jerusalén. Dirigida por José Ángel Ubieta. Bilbao: Desclee de Brower, 1975.

LACAN, Jacques (1959-60). Le seminaire. Livre VII. L'éthique de la psychanalyse. Paris. Seuil, 1986. (Trad. cast: El seminario. Libro VII. La ética en psicoanálisis. Buenos Aires: Paidós, 1988).

\section{Resumos}

Curiosamente, los mitos destinados a dar cuenta de la existencia humana están sometidos a la presencia de la dietética, como una condición inherente a la hominización del hombre. Podemos constatar esa afirmación en los mitos del Génesis, del Theuth y del Padre de la horda primitiva, con el texto Tóten y Tabu. Dicha constatación torna actual el aforismo de Schiller, destacando que el hambre y el amor mueven el universo.

Es um dato que impone, de princípio, un planteamiento sobre la importancia del trazo de la dietética, como una marca en la que el hombre construye, por esa acción, un sentido a la existencia. Com eso, trabajamos con la hipótesis de que la dietética 
posibilita una referencia epistemológica constante para el entendimiento del lugar que el hombre ocupa subjetivamente en una determinada época; $y$, sobre todo, se presenta, como una perspectiva de trabajo psicoanalítico prometedora, cuando ratifica el sujeto como un producto del paso realizado de la natureza a la cultura.

Palabras llave: Dietética y psicoanálisis, mitos y estructuración del sujeto, diatética y subjetivación

Curieusement, les mythes que nous connaissons pour donner une signification à l'existence humaine touchent, sans aucun doute, la présence de la diethétique en tant que condition inherent à l'hominization de l'étre vivent. Cela peut être observée dans les mythes de la Genesis, de Theuth et du Père de la horde primitive, à travers le texte Totem et Tabou. Cette constatation rendra actuel l'aphorisme de Schiller, mettant en évidence que la faim et l'amour apparaîntrent comme le ressort de l'univers.

Tout d'abord, cette question donne lieu a une réflection sur l'importance du trait de la diethétique entant que une marque dans laquelle l'homme construit à travers cette action un sens à l'existence. Par conséquence, travaillons avec l'hipothèse que la diethétique rend possible une reférence epistémique constante pour l'entendement de la place que l'homme subjective dans une époque donnée; et sortout, cette hipothèse se présente comme une ligne prometteuse de travail psychanalytique, quand elle ratifie le sujet en tant qu'un produit du passage de la nature à la culture.

Mots clé: Diethétique e psychoanalisis, mythes e structuration du sujet, diète e subjectivation

Curiously, the myths that we know to give meaning to human existence touch upon, undoubtedly, the presence of dietetic as an inherent condition to the construction of the lived one. This can be found in the myths of Genesis, of Theuth and the Father of Primitive Horde through the Totem and Taboo text. This observation makes Schiller's aphorism updated, emphasizing that hunger and love stand out as the universe spring.

At frist, this theme invites a reflection on the importance of the characteristic of the dietetic as a mark where man constructs through this action, a meaning to his existence. Therefore, we work with the hypothesis that the dietetic creates a constant epistemological reference to the understanding of the place that man occupies subjectively in a given time, and especially, it emerges as a promissing psychoanalitical work line when it ratifies the subject as product of the passage from nature to culture.

Key words: Dietetic and psychoanalysis, myths and structuring of the subject, diets and subjectivation 